\title{
PROFIL HERPES ZOSTER DI POLIKLINIK KULIT DAN KELAMIN RSUP PROF. DR. R. D. KANDOU MANADO 2011-2013
}

\author{
Dwi H. Danardono \\ Nurdjannah J. Niode
}

\author{
Departemen Ilmu kesehatan Kulit dan Kelamin Fakultas Kedokteran \\ Universitas Sam Ratulangi/RSUP Prof. Dr. R.D Kandou, Manado \\ Email: livefortherace@gmail.com
}

\begin{abstract}
Herpes zoster is a reactivation of varicella zoster virus (VZV) that affects the skin and mucosa. The incidence of herpes zoster increases with age. There are three main goals of treatment: overcoming the acute viral infection, relief from acute pain, and prevention of postherpetic neuralgia. This study aimed to determine the profile of herpes zoster in the Dermatology Clinic of Prof. Dr. R. D. Kandou General Hospital for three years based on the number of new cases, gender, ages, dermatome locations, and treatment. This was a retrospective study using the medical records of the Dermatology Clinic of Prof. Dr. R. D. Kandou General Hospital during period January 2011- Desember 2013. The results showed that there were $96(0.84 \%)$ herpes zoster patients of 11,367 new patients, consisted of 51 (53.11\%) males and 45 (46.87\%) females. The most frequent age group was 45-64 years with a number of 59 cases (61.46\%). The most frequent dermatome location was on the left thoracic region with a number of 18 cases (18.75\%). The most widely prescribed treatment was a combination of antiviral agent, analgesic drugs, roborantia, and topical medicine (powder/antibiotic cream), with a number of 43 cases (44.79\%).
\end{abstract}

Keywords: herpes zoster, morbidity

\begin{abstract}
Abstrak: Herpes zoster merupakan reaktivasi virus varicella zoster (VZV) yang menyerang kulit dan mukosa. Insiden herpes zoster meningkat seiring dengan bertambahnya usia. Terdapat tiga tujuan utama pengobatan yaitu: mengatasi infeksi virus akut, mengatasi nyeri akut, dan mencegah timbulnya neuralgia pasca-herpetik. Penelitian ini bertujuan untuk mengetahui profil herpes zoster di Poliklinik Kulit dan Kelamin RSUP Prof. Dr. R. D. Kandou Manado yang meliputi jumlah kasus baru, jenis kelamin, usia, lokasi dermatom, dan terapi. Metode penelitian ialah retrospektif dengan menggunakan catatan medis pasien baru herpes zoster yang berobat di Poliklinik Kulit dan Kelamin RSUP Prof. Dr. R. D. Kandou Manado selama periode Januari 2011 hingga Desember 2013. Hasil penelitian memperlihatkan terdapat $96(0,84 \%)$ kasus herpes zoster dari 11.367 pasien baru yang terdiri dari $51(53,11 \%)$ laki-laki dan 45 (46,87\%) perempuan. Kelompok usia terbanyak ialah 45-64 tahun sejumlah 59 kasus (61,46\%). Lokasi dermatom tersering pada regio torakalis sinistra sejumlah 18 kasus $(18,75 \%)$. Terapi yang paling sering diberikan ialah kombinasi antivirus, analgetik, roboransia, dan pengobatan topikal (bedak/cream antibiotika) sejumlah 43 kasus (44,79\%).
\end{abstract}

Kata kunci: herpes zoster, morbiditas

Herpes zoster disebabkan oleh varicella zoster virus (VZV) yang sama dengan penyebab varisela. Herpes zoster merupakan reaktivasi VZV yang menyerang kulit dan mukosa, ${ }^{1-2}$ dengan gejala nyeri hebat unilateral serta timbulnya lesi vesikuler yang terbatas pada dermatom yang dipersarafi serat saraf spinal maupun ganglion serat saraf sensorik dan nervi kranialis. $^{3-5}$ 
Insiden herpes zoster meningkat seiring dengan bertambahnya usia. Di bawah usia 45 tahun insiden 1 dari 1000 orang; di atas 75 tahun insidennya meningkat 4 kali lipat. Penyakit yang berhubungan dengan imunokompromais seperti infeksi HIV meningkatkan secara drastis faktor risiko herpes zoster. ${ }^{4}$

Patogenesis herpes zoster belum sepenuhnya diketahui. Selama terjadi varisela, VZV berpindah tempat dari lesi kulit dan permukaan mukosa ke ujung saraf sensorik dan ditransportasikan secara sentripetal melalui serat saraf sensoris ke ganglion sensoris. Pada ganglion dorsal terjadi infeksi laten. Virus tersebut tidak lagi menular dan tidak bermultiplikasi, tetapi tetap mempunyai kemampuan untuk berubah menjadi infeksius. Herpes zoster umumnya terjadi pada dermatom sesuai dengan lokasi ruam varisela yang terpadat. Aktivasi VZV laten diduga karena keadaan tertentu yang berhubungan dengan imunosupresi, dan imunitas selular merupakan faktor penting untuk pertahanan pejamu terhadap infeksi endogen. ${ }^{1-4}$

Komplikasi herpes zoster yang terbanyak ialah neuralgia pasca-herpetik (NPH). Menurut Dworkin dan Portenoy definisi NPH yaitu nyeri yang timbul setelah 3 bulan lesi hilang dan jika kurang dari 3 bulan disebut nyeri yang berhubungan dengan zoster (zoster-associated pain). ${ }^{6}$ Usia merupakan faktor yang paling signifikan. Selain pada saraf, komplikasi yang sering terjadi yaitu bakterial superinfeksi atau infeksi sekunder pada kulit. ${ }^{3}$

Secara umum pengobatan herpes zoster mempunyai 3 tujuan utama yaitu: mengatasi infeksi virus akut, mengatasi nyeri akut yang ditimbulkan oleh VZV, dan mencegah timbulnya NPH. ${ }^{1-3}$

\section{METODE PENELITIAN}

Subyek penelitian ini ialah rekam medik pasien Poliklinik Kulit dan Kelamin RSUP Prof. Dr. R. D. Kandou Manado penderita herpes zoster baru periode Januari 2011 - Desember 2013.

Diagnosis herpes zoster ditegakkan berdasarkan anamnesis, pemeriksaan fisik, dan pemeriksan laboratorium berupa sediaan dari kerokan dasar lepuh dengan pewarnaan Giemsa dimana ditemukan sel raksasa berinti banyak.

Hasil pencatatan dikelompokkan berdasarkan jumlah kunjungan baru selama 3 tahun (Januari 2011-Desember 2013) menurut jumlah pasien, jenis kelamin, usia, lokasi dermatom, dan terapi. Variabel penelitian ini meliputi: jumlah pasien, jenis kelamin, usia, lokasi dermatom, dan terapi.

\section{HASIL PENELITIAN}

Selama periode Januari 2011 hingga Desember 2013 terdapat 96 kasus baru herpes zoster, yaitu $0,84 \%$ dari 11.367 pasien baru yang datang berobat ke Poliklinik Kulit dan Kelamin RSUP Prof. Dr. R. D. Kandou Manado. Dari 96 kasus tersebut, terdapat pasien laki-laki sebanyak 51 orang $(53,13 \%)$ dan perempuan sebanyak 45 orang (46,87\%) (Tabel 1).

Dari keseluruhan pasien herpes zoster, kelompok usia 45-64 tahun yang terbanyak yaitu 59 orang $(61,46 \%)$; tidak dijumpai pada kelompok usia $<5$ tahun (Tabel 2).

Tabel 1. Sebaran morbiditas herpes zoster menurut jenis kelamin di Poliklinik Kulit dan Kelamin RSUP Prof. Dr. R. D. Kandou Manado periode Januari 2011 - Desember 2013

\begin{tabular}{ccc}
\hline Jenis kelamin & Jumlah & $\%$ \\
\hline Laki-laki & 51 & 53,13 \\
Perempuan & 45 & 46,87 \\
Total & 96 & 100 \\
\hline
\end{tabular}

Tabel 2. Sebaran morbiditas herpes zoster menurut usia di Poliklinik Kulit dan Kelamin RSUP Prof. Dr. R. D. Kandou Manado periode Januari 2011 - Desember 2013

\begin{tabular}{ccc}
\hline Usia (tahun) & Jumlah & $\%$ \\
\hline$<5$ & 0 & 0 \\
$5-14$ & 1 & 1,03 \\
$15-24$ & 6 & 6,25 \\
$25-44$ & 21 & 21,88 \\
$45-64$ & 59 & 61,46 \\
$>65$ & 9 & 9,38 \\
Total & 96 & 100 \\
\hline
\end{tabular}


Dari segi lokasi dermatom didapatkan herpes zoster torakalis sinistra yang terbanyak yaitu 18 kasus (18,75\%), diikuti herpes zoster torakalis dekstra (16,67\%), dan herpes zoster oftalmika sinistra $(13,54 \%)$ (Tabel 3).

Tabel 3. Sebaran morbiditas herpes zoster menurut lokasi dermatom di Poliklinik Kulit dan Kelamin RSUP Prof. Dr. R. D. Kandou Manado periode Januari 2011 - Desember 2013

\begin{tabular}{clcc}
\hline No & Lokasi dermatom & $\begin{array}{c}\text { Jumlah } \\
\text { pasien }\end{array}$ & $\%$ \\
\hline 1 & fasialis sinistra & 4 & 4,17 \\
2 & fasialis dextra & 5 & 5,21 \\
3 & oftalmikus sinistra & 13 & 13,54 \\
4 & oftalmikus dextra & 11 & 11,46 \\
5 & servikalis sinistra & 6 & 6,25 \\
6 & servikalis dextra & 3 & 3,13 \\
7 & torakalis sinistra & 18 & 18,75 \\
8 & torakalis dextra & 16 & 16,67 \\
9 & lumbalis sinistra & 8 & 8,33 \\
10 & lumbalis dextra & 8 & 8,33 \\
11 & sakralis sinistra & 2 & 2,08 \\
12 & sakralis dextra & 2 & 2,08 \\
& Total & 96 & 100 \\
\hline
\end{tabular}

Tabel 4 memperlihatkan pemberian terapi herpes zoster terbanyak yaitu kombinasi antiviral+analgetik+roboransia + topikal (bedak/cream antibiotik) dengan jumlah 43 kasus (44,79\%). Terdapat 3 kasus $(3,13 \%)$ yang tidak diberikan terapi antiviral.

\section{BAHASAN}

Dari keseluruhan 11.367 pasien baru di Poliklinik Kulit dan Kelamin RSUP Prof. Dr. R. D. Kandou Manado sejak 1 Januari 2011 sampai 31 Desember 2013 didapatkan
$96(0,84 \%)$ kasus herpes zoster. Bila dibandingkan dengan studi retrospektif yang dilakukan oleh Tangkuman YY di Poliklinik Kulit dan Kelamin RSUP Prof. Dr. R. D. Kandou Manado periode Januari - Desember 2005 dengan hasil 25 (0,61\%) dari 4.125 pasien yang datang berkunjung maka telah terjadi sedikit peningkatan. ${ }^{7}$ Hal ini serupa dengan kejadian di luar negeri seperti di Amerika dan Inggris dimana terdapat pola peningkatan insiden herpes zoster dalam dekade terakhir. Awalnya diduga terdapat hubungan dengan maraknya penggunaan vaksin varisela, namun beberapa studi terakhir menyatakan penyebab peningkatan insiden herpes zoster masih belum bisa dijelaskan. ${ }^{8}$

Pada penelitian ini jumlah pasien herpes zoster laki-laki lebih banyak dibandingkan perempuan, yaitu sebanyak 51 orang $(53,13 \%)$ sedangkan perempuan sebanyak 45 orang (46,87\%) (Tabel 1). Hasil yang sama juga didapat di beberapa RS Pendidikan lain seperti di Medan (53,51\%), Solo (53,03\%), dan Makasar (52,91\%). Hal ini berbeda dengan data dari RS Pendidikan di Bandung, Yogyakarta, Surabaya, dan Malang dimana jumlah pasien perempuan lebih banyak dibandingkan laki-laki. ${ }^{9}$ Menurut Sterling morbiditas herpes zoster antara laki-laki dan perempuan sama. ${ }^{2}$

Diantara seluruh pasien herpes zoster, kelompok usia 45-64 tahun yang terbanyak yaitu sebesar 61,46\% (Tabel 2). Hasil yang sama didapatkan di beberapa RS Pendidikan pada periode yang sama, seperti di Bandung (38,52\%), Medan (82,35\%), dan Solo (46,97\%).

Tabel 4. Terapi Herpes Zoster di Poliklinik Kulit dan Kelamin RSUP Prof. dr. R.D. Kandou Manado dari Januari 2011 - Desember 2013

\begin{tabular}{lcc}
\hline \multicolumn{1}{c}{ Jenis obat } & Jumlah & $\%$ \\
\hline Antiviral + analgetik + roboransia & 18 & 18,75 \\
Antiviral + analgetik + roboransia + topikal & 43 & 44,79 \\
Antiviral + antibiotik oral + analgetik + roboransia + topikal & 15 & 15,63 \\
Antiviral + analgetik + topikal & 17 & 17,70 \\
Analgetik + topikal + roboransia & 3 & 3,13 \\
Total & 96 & 100 \\
\hline
\end{tabular}


Dari total seluruh RS Pendidikan di Indonesia juga didapatkan hasil yang sama $(41,38 \%){ }^{9}$

Faktor risiko herpes zoster dipengaruhi oleh usia. Makin tinggi usia maka makin rentan untuk terjadinya herpes zoster. Selain itu, menurunnya imunitas juga berpengaruh terhadap reaktivasi VZV. ${ }^{1-4}$

Pada penelitian ini lokasi dermatom yang paling banyak terkena herpes zoster ialah torakalis sinistra yaitu 18 kasus (18,75\%). Hasil yang sama juga didapat dari penelitian sebelumnya oleh Tangkuman YY di Poliklinik Kulit dan Kelamin RSUP Prof. Dr. R. D. Kandou Manado periode Januari - Desember $2005{ }^{7}$ Data distribusi dermatom paling sering menurut Sterling serta Odom et al. juga di daerah torakalis yaitu lebih dari $50 \%$.,4 Belum ada penelitian yang menjelaskan mengapa daerah torakalis paling sering terkena. Hal ini mungkin disebabkan dermatom torakalis paling dekat dengan letak ganglion dorsalis.

Dari penelitian ini didapatkan terapi yang paling sering diberikan ialah kombinasi antiviral, analgetik, roboransia, dan topikal (bedak/cream antibiotik), dengan jumlah 43 kasus (44,79\%). Sesuai dengan acuan pustaka, antiviral merupakan terapi utama dalam mengobati herpes zoster. Pemberian analgetik hanya bersifat simtomatik untuk mengatasi nyeri. Roboransia diberikan sebagai neuroprotektor mengingat patofisiologi herpes zoster yang mengenai saraf. Untuk mencegah pecahnya vesikel maka diberikan topikal bedak sedangkan pada vesikel yang sudah pecah/ulserasi diberikan topikal cream antibiotik. Sebanyak 3 kasus herpes zoster tidak diberikan antiviral. Hal ini mungkin disebabkan pada saat pasien datang berobat durasi herpes zosternya sudah terjadi lebih dari 72 jam dan tidak terdapat indikasi lain seperti ensefalitis, gangguan nervus kranialis, dan adanya komplikasi mata. Pemberian terapi antivirus akan optimal bila diberikan kurang dari 72 jam mengingat mekanisme kerja antiviral ialah menghambat replikasi DNA virus. ${ }^{3}$ Terdapat 15 kasus (15,63\%) yang mendapat kombinasi dengan antibiotik oral. Alasan pemberian antibiotik oral pada kasus tersebut ialah terdapatnya komplikasi berupa infeksi sekunder.

\section{SIMPULAN}

Telah dilaporkan suatu tinjauan retrospektif kasus herpes zoster di Poliklinik Kulit dan Kelamin Prof. Dr. R.D. Kandou Manado periode Januari 2011 - Desember 2013. Kasus herpes zoster lebih banyak ditemukan pada laki-laki daripada perempuan. Morbiditas tertinggi pada usia 45-64 tahun dengan lokasi dermatom paling sering pada regio torakalis sinistra. Terapi yang paling sering diberikan ialah kombinasi antiviral, analgesik, roboransia, dan topikal (bedak/cream antibiotik).

\section{SARAN}

Diharapkan agar pencatatan rekam medik yang lengkap dan detail dapat terus dilanjutkan agar studi retrospektif mengenai herpes zoster bisa menjadi bahan masukan bagi kelompok studi herpes zoster di Indonesia.

\section{DAFTAR PUSTAKA}

1. Madkan V, Sra K, Brantley J, Carrasco, Mendoza N,Tyring SK. Human herpes viruses In: Bolognia JL, Jorizzo JL, Schaffer JV, editors. Dermatology Vol. 1 (2nd ed.). Philadelphia: Elsevier, 2008; p. 1204-8.

2. Sterling JC. Virus infection. In: Burns T, Breathnach S, Cox N, Griffiths C, editors. Rook's Textbook of Dermatology (8th ed.). Oxford: WileyBlackwell, 2010; p. 22-33.

3. Straus SE, Oxman MN, Schmader KE. Varicella and herpes zoster. In: Wolff K, Goldsmith LA, Katz SI, Gilchrest BA, Paller AS, Leffell DJ, editors. Fitzpatrick's Dermatology in General Medicine (8th ed.). New York: McGraw Hill, 2012; p. 2383-401.

4. Odom RB, James WD, Berger TG. Viral diseases. In: Andrew's Disease of the Skin (10th ed.). Philadelphia: WB Saunders, 2006; p. 379-84. 
5. Handoko R. Penyakit virus. In: Djuanda A, Hamzah M, Aisah S, editors. Ilmu Penyakit Kulit dan Kelamin (Edisi ke6). Jakarta: FK UI, 2010; p.110-8.

6. Ursini T, Tontodonati M, Polilli E, Pippa L, Parruti G. Zoster-associated pain and post herpetic neuralgia. In: Magel GD, editor. Herpesviridae - A look into this unique family of viruses. InTech. 2012; p. 137-72. Available from: http://www.interchopen.com/books/herp esviridae-a-lool-into-this-unique-familyof-viruses/zoster-associated-pain-andpost-herpetic-neuralgia.

7. Sahriani HR, Kapantow MG, Pandaleke HEJ. Profil herpes zoster di Poliklinik
Kulit dan Kelamin RSUP Prof. Dr. R. D. Kandou periode Januari-Desember 2012 [Skripsi]. Manado: Universitas Sam Ratulangi; 2013.

8. Reynolds MA, Chaves SS, Harpaz R, Lopez AS, Seward JS. The impact of the varicella vaccination program on herpes zoster epidemiology in the United States: A review. J Infect Dis. 2008;197(Suppl.2):S224-S227. DOI: 10.1086/522162.

9. Pusponegoro EHD, Nilasari H, Niode NJ, Daili SF, Djauzi S, Lumintang $\mathbf{H}$. Buku Panduan Herpes Zoster di Indonesia. Jakarta: Badan Penerbit FK UI, 2014. 